\title{
The missional renaissance: Its impact on churches in South Africa, ecumenical organisations, and the development of local congregations
}

\begin{tabular}{|c|c|}
\hline $\begin{array}{l}\text { Author: } \\
\text { Jerry Pillay }{ }^{1}\end{array}$ & \\
\hline $\begin{array}{l}\text { Affiliation: } \\
{ }^{1} \text { Department } \\
\text { History and } \mathrm{Cl} \\
\text { Faculty of The } \\
\text { University of } \\
\text { South Africa }\end{array}$ & $\begin{array}{l}\text { f Church } \\
\text { urch Polity, } \\
\text { logy, } \\
\text { retoria, }\end{array}$ \\
\hline $\begin{array}{l}\text { Corresponder } \\
\text { Jerry Pillay }\end{array}$ & ce to: \\
\hline $\begin{array}{l}\text { Email: } \\
\text { jerry.pillay@u }\end{array}$ & .ac.za \\
\hline $\begin{array}{l}\text { Postal addres } \\
\text { Private Bag X2 } \\
0028 \text {, Pretoria }\end{array}$ & $\begin{array}{l}\text { 0, Hatfield } \\
\text { South Africa }\end{array}$ \\
\hline $\begin{array}{l}\text { Dates: } \\
\text { Received: } 02 \mathrm{~J} \\
\text { Accepted: } 07 \\
\text { Published: } 28\end{array}$ & $\begin{array}{l}\text { une } 2015 \\
\text { uly } 2015 \\
\text { Sept. } 2015\end{array}$ \\
\hline $\begin{array}{l}\text { How to cite th } \\
\text { Pillay, J., } 2015 \\
\text { renaissance: It } \\
\text { churches in So } \\
\text { ecumenical or } \\
\text { and the devel } \\
\text { of local congre } \\
\text { HTS Teologies } \\
\text { Theological St } \\
\text { Art. \#3065, } 6 \\
\text { dx.doi.org/10. } \\
\text { v71i3.3065 }\end{array}$ & $\begin{array}{l}\text { is article: } \\
\text { 'The missional } \\
\text { s impact on } \\
\text { uth Africa, } \\
\text { ganisations, } \\
\text { pment } \\
\text { gations', } \\
\text { Studies/ } \\
\text { Idies 71(3), } \\
\text { ages. http:// } \\
4102 / \text { hts. }\end{array}$ \\
\hline $\begin{array}{l}\text { Copyright: } \\
\text { C 2015. The A } \\
\text { Licensee: AOS } \\
\text { OpenJournals } \\
\text { licensed unde } \\
\text { Commons Attr } \\
\text { License. }\end{array}$ & $\begin{array}{l}\text { uthors. } \\
\text { This work is } \\
\text { the Creative } \\
\text { ibution }\end{array}$ \\
\hline Read online: & \\
\hline 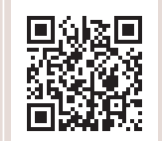 & $\begin{array}{l}\text { Scan this QR } \\
\text { code with your } \\
\text { smart phone or } \\
\text { mobile device } \\
\text { to read online. }\end{array}$ \\
\hline
\end{tabular}

This article focuses on three matters pertaining to the conversation of missional churches. Firstly, it looks at the impact of missional awareness in South Africa and Africa. Here the article explores what is meant by missional congregations in the South African context. Secondly it looks at the ecumenical understanding and development of the missional church and how this has started to shape ecumenical organisations and, thirdly it concludes with some suggestions of how missional congregations and denominations can be developed. In this final section the article offers some strategic principles for developing missional churches.

\section{Missional movement in South Africa}

Missional seems to be the buzz word today. Reggie McNeal (2009:xiii) states that the rise of the missional church is the single biggest development in Christianity since the Reformation. He points out that this is not doing church-as-usual. Going missional requires three shifts: (1) from internal to external in terms of ministry focus, (2) from program development to people development in terms of core activity and (3) from church-based to kingdom-based in terms of leadership agenda (McNeal 2009:xiv). Speaking about the missional renaissance, McNeal asserts that this is changing the way the people of God think about God and the world, about what God is up to in the world and what part the people of God play in it. It requires a paradigm shift.

This missional craze has of course also impacted on South Africa and Africa as a whole. Virtually most denominations are talking about becoming missional churches. Pastors and church leaders are keen to know what they can do to establish missional congregations. The impact of the missional gurus such as Barth, Leslie Newbigin and Bosch are being studied at universities and theological seminaries. The Fresh Expressions movement emerging in Europe has found its way into Africa. I may add that this is different from the church growth model which primarily focuses on building the local church. This is not about making the church attractable, but missional. It is not about bringing people into the church, it is about taking the church into the world - to transform the world to reflect the glory of God and God's kingdom or sovereign rule. Some congregations have undertaken missional surveys to help them find their missional focus and niche. The motivation is not always pure because financial challenges to sustain a congregation and/or denomination, apathy, aging membership, declining membership and disinterested youth are some of the reasons that drive interest. The focus is not necessarily missional but attractional - how do we get people to church? It requires a paradigm shift.

Perhaps it is appropriate at this point to ask the question: What is a missional church? To answer this question we need to first understand what Christian mission is. Attempts to define Christian mission have resulted in prolonged and relentless debates. Even more difficult is the task of determining the aims of mission. If we attempt a more specifically theological synopsis of 'mission' as the concept has traditionally been used, we note that it has been paraphrased as (1) propagation of the faith, (2) expansion of the reign of God, (3) conversion of the heathen and (4) the founding of new churches (Müller 1987:31-34). In essence, Christians, depending from which tradition and denomination you come, have emphasised different aspects and understandings of mission. Mission is seen as the saving of souls, service (diakononia), worship (leiturgia), transformation of the society, community and world, humanisation, community development, planting of churches, et cetera. To emphasise one or more aspects of mission does not render it wrong, it is just incomplete in the comprehensive biblical understanding of mission. Emilio Castro states that we are called as human beings to participate in the coming of God's Kingdom. This kingdom has to do with the welfare of the whole person, not excluding the social, political and economic aspects of life (Castro 1985:56-60). The focus on the kingdom (reign of God) provides a comprehensive summary of what Christian mission is all about. Kritzinger (1988) selects the 
theme of the kingdom of God in his definition of Christian mission. He says:

We understand Christian mission to be a wide and inclusive complex of activities aimed at the realisation of the reign of God in history. It includes evangelism but is at the same time much wider than that. Perhaps one could say that mission is the 'cutting edge' of the Christian movement - that activist streak in the church's life that refuses to accept the world as it is and keeps on trying to change it, prodding it on towards God's final reign of justice and peace. (p. 34)

Still, others claim that the kingdom has come when the spiritual needs of humankind are satisfied; kingdom involves the forgiveness of sins. Castro, however, states that nowhere does the New Testament spiritualise the kingdom of God or limits it to the spiritual side of nature. Verkuyl (1978:203) points out that the kingdom to which the Bible testifies involves a proclamation and a realisation of a total salvation, one which covers the whole range of human needs and destroys every pocket of evil and grief affecting humankind. He adds that the kingdom of the New Testament has a breadth and scope which is unsurpassed; it embraces heaven as well as earth, world history as well as the whole cosmos.

It is still true that many churches tend to focus on mission as being 'saving souls'. This is of course no different in Africa or South Africa for that matter. In the context of Africa because of its challenges of poverty, oppression, hunger, et cetera, we have always had a notion of what I would refer to as missional evangelism. Although some Christians may have argued against any involvement in politics they, nevertheless, realised that they could not proclaim the gospel of Jesus Christ in words only but should also do so in concrete praxis. ${ }^{1}$ Even the early missionaries in Africa have always implicitly assumed that the reception and the living out of the gospel would begin to transform both individual and community life. While we recognise today that the missionaries often envisioned a model of the transformed community that looked suspiciously like the ones they knew in their own cultures, there is no doubt that this transforming dimension was an essential aspect of mission. ${ }^{2}$

Although the holistic concept of mission is largely embraced today the different emphases and aspects of mission still remain with us. Needless to say, that these impact and add to the complexities of defining the missional church. In my view, to summarise, a missional church is one that is centred in the good news of Jesus Christ and the Triune God; has a broad view of mission; focuses on the kingdom of God as it works for justice, peace and righteousness on earth; and leads people to faith in Jesus Christ as it seeks to transform both the individual and the environment.

Rob Wegner offers some insightful characteristics of a missional church in his description of at least fifteen 'missional

\footnotetext{
1.For example, we see this in South Africa today in Pentecostal and Charismatic Churches that never really became involved in the struggle against apartheid, who are now at the forefront of transforming society.
}

2.For a deeper exploration of this claim, see Pillay (2001:119-127). moves' (Wegner \& Magruder 2012). Such churches he says move from: Saved souls to saved wholes, missions to mission, my tribe to every tribe, centre to the margins, top to bottom up, diffused to focused, transactional to transformational, relief to development, professionals to full participation, from formal to fractal leadership, institution to movement, from 'we can do it; you can help' to 'you can do it, we can help', and from Great Commission to Great Completion.

The missional renaissance has hit South Africa. The majority of church leaders and churches want to catch that missional fire or wave. Whatever their reasons may be, at least one thing is for sure: We have to look at new ways of being church. Although mission talks about doing, it actually starts with being church: The realisation that we are called and sent by God into the world to be God's presence. We have the privilege and responsibility to share in the missio Dei (God's mission). Mission cannot be something attached to the church, it must be the function of the church with the realisation that the church is the function of mission. Whilst churches in South Africa are making missional moves, it must be observed that it is not sufficient to embrace this in vision and mission statements, it must also become part of the DNA of the church; meaning that denominations and churches have to reframe this DNA from a missional perspective which impacts on its ecclesiology and polity. Craig van Gelder (2008:10) makes the latter point whilst asserting that 'denominations are not going to go away; however, they are going to continue to morph within our ever-changing cultural context'. He further states that we need to bring missional imagination to bear on rethinking, reframing and reclaiming denominations in the midst of the transition they are presently experiencing (Van Gelder 2008:11).

It may be true to say that whilst many denominations in South Africa are thinking missional they are far from the attempt of shaping its DNA from a missional perspective. However, I wish to note the concerted effort in this area by the Dutch Reformed Church who has already adopted a paper on mission ecclesiology. It is also good to note that churches from different denominational backgrounds have already come together to discuss various matters related to the formation of missional churches. This has emerged from the Fresh Expressions ${ }^{3}$ initiatives in South Africa. One can only hope that these initiatives can add fuel to the missional fire in South Africa and Africa as a whole. I turn now to look at the contributions of ecumenical organisations in missional thinking.

\section{Ecumenical missional thinking}

Most of the ecumenical organisations today have embraced a more firm focus on mission. This can be particularly seen in their vision and mission statements. Almost all of the organisations that I am personally involved with have included in their mission statement the need to work towards the 'fullness of life in Jesus Christ' based on John 10:10. And in

3.Fresh Expressions is a movement started in Europe by the Anglican and Methodist Churches. 
this is embedded their participation and partnership in God's mission in the world. For example, the World Communion of Reformed Churches (WCRC) has always understood its work from a mission perspective, but in formulating a new vision and mission statement in 2010 it ensured that mission was intentionally mentioned as its first strategic direction as an organisation focusing on: mission, communion, justice, theology and ecumenical partnerships. ${ }^{4}$ Undergirding all these is the directive of engaging God's mission in the world with others.

The Council for World Mission (CWM) also made this central to its work. In fact it reorganised and strategised itself to provide missional empowerment for its 31 member churches. It has over the last 9 years requested all its member churches to embark on a plan to establish missional-shaped denominations and local congregations. Another notable effort in all these is that they have completely restructured themselves as an organisation to develop and support missional congregations. They have also provided and still avail vast amounts of funding to member churches that are keen to focus on mission. Even churches that were not thinking mission have been brought into it in order to access the possibilities of funding. Though the intentions may have not been noble at the beginning, these churches have now got into the rhythm of what it means to be missional. These organisations have adopted the broad or holistic view of mission which transcends the mere saving of soul's notion to speak and act in favour of transforming the world.

In 2012 the World Council of Churches (WCC) adopted Together towards life: Mission and evangelism in changing landscapes. This document provides a very comprehensive view on Christian mission; it aims at a renewed understanding and practice of mission and evangelism in changing landscapes (WCC 2013). It calls for a commitment to fullness of life for all, led by the God of Life. The document which emerged through the work of the Commission on World Mission and Evangelism (CWME) offers a most comprehensive view of mission under the ministry of the Holy Spirit within the will of the Triune God. It speaks about mission under four main headings: Spirit of Mission: Breath of Life, Spirit of Liberation: Mission from the Margins, Spirit of Community: Church on the move and Spirit of Pentecost: Good News for all. They provide 10 affirmations for mission and evangelism today. It is not possible to discuss these within the scope of this presentation but suffice it to say that these embrace dynamism, justice, diversity and transformation as key concepts of mission today. Of particular significance is that these affirmations speak of the role of the church in mission and affirm local church initiatives in mission.

Ecumenical organisations are saying a few things: It is God's mission and we must partner with others in transforming the world. We must embrace the holistic view of mission. We must help churches to go outside the gate (from internal

4.The WCRC was formed in June 2010 with the uniting of the World Alliance of Reformed Churches (WARC) and the Reformed Ecumenical Council (REC). For more information consult http://www.wcrc.ch to external) and the local congregation is most essential for mission - it is where mission happens. We need to put our energy and focus on local congregations, empowering and enabling them to be missional shaped. In fact this is the future of ecumenism since it is struggling, to be sustained institutionally; its success lies in a relational model.

This ecumenical impact on missional thinking can be seen in South Africa today. Many are of the opinion that ecumenism in South Africa is dying and this view is largely associated with the struggles of the South African Council of Churches (SACC) to survive, mainly financially. In my opinion, ecumenism is not dying instead it is morphing into something new. This new development is not driven by ecclesiology, doctrine, tradition or denominationalism but by a missional focus. The essential question is: How can we work and/or partner together in God's mission in transforming society and country? How can we exercise a prophetic voice together? How can we journey with the poor? The evangelical churches, in particular, are at the forefront seeking to influence government and business with the gospel. Sometimes one wonders whether their goal in mission is Christianisation or transformation. Whatever the intentions, one thing is sure we are experiencing what I call a missional revolution with the intention of inspiring, motivating, equipping and nurturing Christian disciples. We are realising that the goal is not to get people to church but to get the church into the world - to transform the world with the justice and peace of God. But how do we do this? This is the purpose of the next section.

\section{How to develop missional shaped churches?}

In this time of the missional renaissance much has been written about missional churches and missional leaders. So it is not my intention to give an in-depth practical guide to how you can go about developing missional congregations or denominations (see McNeal 2009; Van Gelder 2007, 2008; Wegner \& Magruder 2012 for some good ideas on how to establish missional congregations and denominations). Instead in this section I aim to offer some broad principles that should undergird the missional endeavour. And to do this, I will draw from the prophet Nehemiah whom I consider to be a missional leader. ${ }^{5}$ Let me begin by stating that as we set out to develop missional congregations there are at least four essential missional questions we need to ask: (1) What is the mission context? (2) What is God already doing in this context (3) What is God calling us to do? and (4) How can we do what God is calling us to do in such a context? We see this in what I propose below as the Nehemiah model of mission. Darrell Guder states that the 'proclamation of the gospel' is to be understood and practiced as the 'form of the kingdom of God.' This convergence of kingdom and king, mission and message, has profound implications for our theological

5.Some Old Testament scholars dispute the idea of the missionary movement in the Old Testament (OT). However, my description of Nehemiah as a missional leader is used in the context that he was given a mission from God to rebuild the walls of is used in the context that he was given a mission from God to rebuild the walls of
Jerusalem. 
task (Guder 2000:46). This is what I attempt to show in the reference to Nehemiah.

\section{Missio Dei: God's mission}

Nehemiah had a great sense of closeness to God (Neh 1:5-11). He realised that where he was and the position he held as cupbearer to the king was solely by the grace and blessings of God. In his spirit and living he wanted to be pleasing and obedient to God. When the time of testing came he chose to remain faithful to the call of God instead of remaining with the king. More significantly, one of the things we discover repeatedly in the book of Nehemiah is that he was a man of prayer. When he heard that the wall of Jerusalem was broken down, we are told that he mourned and fasted and prayed for some days (1:4). When he spoke to the king we are told that he 'prayed to God' (2:4). When he faced opposition, he prayed (chapters 4 \& 6). In fact if you read Nehemiah you will learn that everything he did was saturated by prayer.

Spirituality must be the first building block to rebuild or reform both church and society. It reminds us that what we refer to as our mission is actually God's mission. God calls us to participate in God's mission in transforming the world. The Missionary Conference in Willingen (1952) made this point:

[Even] the church cannot be the starting point for a theology of mission: the origin of mission is found in the triune God, from whose nature and purpose the church receives the commission, impulse and power to engage in mission. (Anderson 1955:10)

We need a mission spirituality that is embedded in worship, devotion and obedience, which reminds us that we are in God's mission, not our own. The church in mission can only be sustained by being spirituality deeply rooted in the Trinity's communion of love. So, even though our encounter with the Triune God is inward, personal and communal, it should also direct us outward in missionary endeavour, for we are led by the Spirit into various situations and moments, into meeting points with others, into spaces of encounter and into critical locations of human struggle (WCC 2013:57). All of the above implies that mission spirituality is always transformative. But it also stresses that it all begins with God. This ought to be the starting point when we seek to build missional congregations.

\section{Mission and context}

When news reached Nehemiah that the wall of Jerusalem was broken, we are told that he wept, mourned, fasted and prayed. He was deeply troubled. You see it was not just about the wall. There was something more going on here. The wall spoke of the security and safety of the city of Jerusalem but more than that it meant the protection of the Temple and more than that, it meant the presence of God. Nehemiah did not want the presence of God to leave the city with the destruction of the Temple. Therefore in building the wall he was on a bigger mission of God. He took time to understand the context, analyse the situation and ascertain what was needed. He focused on what God was already doing in the context and then considered what God was calling him to do. He knew his mission. He had to rebuild the wall of Jerusalem.

It is important for the church to understand the context, analyse the situation, gather the facts, do its research sometimes teaming up with others in this endeavour and know its mission. What is God calling her to do? The church's mission looks with 'living hope' (1 Pt 1:3) toward the completion of the work God has begun in Jesus Christ, and this hope is firmly established in God raising Jesus from the dead (Guder 1998:46). As an agent of hope then, the church needs the wisdom to constantly evaluate, assess, analyse and read the signs of the times. The church needs the courage to call the statements and actions of political leaders into question when they go astray and implement systems that favour just a few. The church must serve as the moral conscience of society and ask the deeper justice questions and challenge structures that perpetuate inequalities in society. This is what Nehemiah did when he took up the cause of the poor as recorded in chapter 5 and this is precisely what we are called to do as a church, as we rebuild the walls of both society and the church. Let us not become comfortable with sin and suffering. We are on God's mission. We must become restless in the face of godlessness, injustices, immorality, violence and poverty. Arias (1984) expresses this well in pointing out that the kingdom of God is forcing its way and demanding a powerful reaction:

The Kingdom is in-breaking - forcing its way in through persons, institutions, and societies, attracting and repelling, being seized by faith, and being rejected by unfaith. The presence of the kingdom in Jesus Christ is opening its way among the people, forgiving sins, restoring life, creating community, but at the same time exacerbating the forces of the anti-kingdom that will take him finally to the cross. The presence of the in-breaking kingdom provokes a confrontation and demands an option. (p. 44)

The church needs the Nehemiah type of leaders not so much to build walls but to build bridges. God wants us to build bridges to reach the lost, the suffering, the forsaken and the poor. Bridges to create a new world filled with faith, hope and love - bridges that lead to fullness of life in Jesus Christ. This is what it means to be missional. A missional leader is a bridge builder and a missional congregation builds bridges in a society divided by race, culture, politics, religion, et cetera. These are signs of the in-breaking kingdom.

Missional spirituality compels missional leadership into missional discernment. In other words, a key aspect where missional leadership is concerned is with the discernment of (the) missional vocation' (Van Kooten \& Barrett 2004:139). It is the priority task of missional leadership to constantly refocus the congregation's attention towards God, to discern in faith whether God is present, where he is already at work in the congregation's context through his Spirit, in order to determine where the congregation can become an active part 
of God's already existing mission (Cordier 2014:82). Speaking to this thought Niemandt (2014) points out that:

[A] missional spirituality steers clear of the idea that God is distant and uninvolved in daily life - a missional theology builds upon the foundation that God is present and involved, and that His desire is for the transformation of individuals, groups and institutions. (p. 7)

Niemandt (2014) further asserts

it is for this reason that discernment is such an important and decisive first step in the process of joining God in God's mission; and one of the key aspects of missional leadership, along with creativity and innovation. (p. 7)

To summarise then, a missional congregation looks to God and the context in which the congregation is found; understanding the realities of such context it discerns its missional vocation and seeks to transform that context with the justice, peace and love of God, relying on the Holy Spirit to lead her as she attempts to be God's presence in that context and beyond.

\section{Missional message}

Nehemiah was not on his own mission. He was on God's mission. He had a message from God that he was prepared to proclaim. He called the people of Israel together not only to build the wall but to give them the message of God: Repent, Remember and Return. We see this quite powerfully from chapters 8 onwards where he calls for fasting, prayer, consecration, purity and obedience to God.

What is the message of the church today? The Apostle Paul tells us that the message of the Gospel is Christ incarnate, crucified, dead, risen and coming back again - that is the missional message we should be proclaiming as we apply this gospel message to the (any) given context. Instead many get caught up in preaching the 'prosperity gospel' and a watered-down message that features 'positive thinking' and they tell itching ears what they want to hear. Good as it may sound that is not the message of the Gospel. The missional message is 'fullness of life in Jesus Christ'.

The church, too, is so much like the world. It is corrupted by the quest for power, position and materialism. It is often complicit or silent in the midst of evil, suffering, political turmoil and economic discrepancies and thus loses it prophetic witness, message and ministry. We are called to speak truth to people, to our own structures and practices and to power. We offer a prophetic (missional) message with love.

In referring to Newbigin's understanding of the eschatological nature of the church which, pointing to hope, tells us that God invites all creation to participate in God's new creation, Niemandt (2014) makes the point that:

[T] his means that the church will have to learn to look differently at the world - with a hermeneutic of love, one that expects to see the living God's works of love in this world. (p. 9)
He then refers to the questions posed by Heath (2008):

What if we looked at our world ... with pity and not blame? What if we heard God's call to evangelise out of love instead of fear, hope instead of judgement? What if we saw sin for the complex mixture it is, grounded in wounds and unmet needs? What if we automatically tried to see the 'total fact' of others? In short, what would it mean to read our world with a hermeneutic of love? (p. 119)

This does not mean that we tolerate anything and everything that goes on in the world. It means that we speak the truth with love! As Bosch (1991) puts it:

Whenever God's good news is made known, the bad news of our human reality is also revealed. As the kingdom approaches, it launches an all-out attack on evil in all its manifestations. (p. 32)

Guder (2000) points out that the message of Jesus' death on the cross will encounter resistance as described by the Apostle Paul as 'a stumbling block to Jews and foolishness to Gentiles' (1Cor 1:22). However, Guder asserts that a gospel that speaks of new beginnings and envisions a radically different kind of world may gain a hearing, even if it uses the somewhat arcane language of 'the kingdom of God' (Guder 2000:40). A gospel that is candid about the struggles, injustices, and cruelty of human existence will possibly be respected. Guder (2000) adds further that we must not lose sight of the Christocentric theological dimension of the message without undermining the Trinitarian basis of Christian theology. Since Jesus Christ is both the message and the messenger, the good news himself, we can never move far from the one who is sent and who sends, the risen Lord. 'Mission is ... a predicate of Christology'. Jesus himself is 'the primal missionary' (Guder 2000:48).

\section{Mission method}

Nehemiah knew that the task of rebuilding the wall was not an easy one. He faced opposition right from the beginning. He was not afraid because he counted on the presence of God. He knew that God was with him and he could not fail: 'The God of heaven will give us success' (Neh 2:20). Nehemiah had a method and strategy as to how he was going to build the wall of Jerusalem. The book details how he went about his mission. He knew God was with him but that didn't stop him from planning. He trusted God to do God's part and he did not fail to do his own. Even his opposition saw that he had a method in his madness - they taught that he was mad when he set out to rebuild the wall of Jerusalem.

As the church engages in God's mission in the world it needs to have planning and strategy in mission. It needs to know its mission, set out its goals and objectives, gather its resources, evaluate its achievements and celebrate its successes. Nehemiah shows us this in chapter 8 where he calls the people to celebrate with great joy (Neh 8:12). Sometimes in the church we do not know how to celebrate, give thanks and to offer gratitude both to God and the people who share in God's mission. The fitting response to the 
continuing experience of God's goodness is celebration and thanksgiving (Guder 2000:31).

The world is challenged by injustice, violence, secularisation, religious pluralism, religious conflicts, a sexual revolution, and the list can go on. What is our strategy and plan to reach the world around us and to make a difference? What is our plan to build a church that Jesus prayed for in John 17? What kind of church is this? The Nicene Creed describes this for us: one, holy, catholic and apostolic.

The church as apostolic tells us that it is a 'called out and sent out community' (Nicene Creed). We are called by our Triune God, blessed by his presence and sent out to call and bless others in his name. We come so that we may 'go and make disciples'. The church does not exist just for believers, it actually exists for the world: To lead others to Jesus. The apostolic dimension reminds us that we are a missionary church, the people of God constantly on the march for God. So we should always be equipping and sending Christians out to serve the world in the love of Jesus. When our hands and feet are at work to serve the world in Christ they will see Christ in us without we having to say anything. But this is not going to happen if we do not consciously serve the world in God's love. If we do not seek to become missional churches participating in God's mission in transforming the world.

\section{Conclusion}

The missional renaissance is with us. I have tried to show, in this article, its impact and development in South Africa and on the ecumenical movement. In my opinion, this missional focus is going to renew, restore and revitalise the church in its ministry and relevance in the world. However, we need to recognise and assume our place not as a church with mission but as a mission church. This would mean rethinking the structures, polity and the way we 'do' church today. It would mean rethinking our denominational DNA from a missional perspective and embracing a missional ecclesiology that enables the church to be and to do what it is called to do as it proclaims the good news of Christ to the world. In this the local church and/or congregation have a very central and definite role to play because, in essence, this is where mission happens. Perhaps the Nehemiah model which I have proposed, knowing God's mission, message, and method, will help us to continue to develop missional congregations.
What we need is missional imagination (Hirsch \& Catchim 2012:23). Imagine what would happen to this country and world if churches become truly missional.

\section{Acknowledgements Competing interests}

The author declares that he has no financial or personal relationships which may have inappropriately influenced him in writing this article.

\section{References}

Anderson, W., 1955, Towards a theology of mission: A study of the encounter between the missionary enterprise and the church and its theology, SCM, London. (International Missionary Council Research Pamphlet, 2).

Arias, M., 1984, Announcing the reign of God: Evangelization and the subversive memory of Jesus, Fortress, Philadelphia, PA.

Barrett, L.Y. (ed.), 2004, Treasure in clay jars: Patterns in missional faithfulness, Eerdmans, Grand Rapids, MI.

Bosch, D., 1991, Transforming mission: Paradigm shifts in theology of mission, Orbis Books, Maryknoll, NY.

Castro, E., 1985, Freedom in mission: The perspective of the Kingdom of God: An ecumenical inquiry, World Council of Churches, Geneva.

Cordier, G.S., 2014, 'Kernkapasiteite van die predikant as missionaleleier in die vorming van ' $\mathrm{n}$ missionale gemeentekultuur', PhD thesis, Dept. Science of Religion and Missiology, University of Pretoria.

Guder, D.L. (ed.), 1998, Missional church: A vision for the sending of the church in North America, Wm. B. Eerdmans Publishing Company, Grand Rapids, MI.

Guder, D.L., 2000, The continuing conversion of the church, Wm. B. Eerdmans, Grand Rapids, $\mathrm{MI}$

Heath, E.A., 2008, The mystic way of evangelism: A contemplative vision for Christian outreach, Baker Academic, Grand Rapids, MI.

Hirsch, A. \& Catchim, T., 2012, The permanent revolution: Apostolic imagination and practise for the 21st Century Church, Jossey-Bass, San Francisco, CA.

Kritzinger, J.N.J., 1988, The South African context for mission, Lux Verbi, Cape Town.

McNeal, R., 2009, Missional renaissance: Changing the scorecard for the church, Jossey-Bass, San Francisco, CA.

Müller, K., 1987, Mission theology: An introduction, Steyler Verlag, Nettetal.

Niemandt, C.J.P., 2014, 'Developing missional congregations', paper presented at the Council for World Mission Africa Region Assembly, Johannesburg, 13th June.

Pillay, J., 2001, 'The church and development: Towards a theology of development', $\mathrm{PhD}$ thesis, Dept. of Religious Studies, University of Cape Town.

Van Gelder, C. (ed.), 2007, The missional church in context: Helping congregations develop contextual ministry, Eerdmans, Grand Rapids, MI.

Van Gelder, C. (ed.), 2008, The missional church \& denominations: Helping congregations develop a missional identity, Eerdmans, Grand Rapids, MI.

Van Kooten, J. \& Barrett, L.Y., 2004, 'Missional authority', in L.Y. Barrett (ed.), Treasure in clay jars: Patterns in missional faithfulness, pp. 139-148, Eerdmans, Grand Rapids, MI.

Verkuyl, J., 1978, Contemporary missiology, Eerdmans, Grand Rapids, MI.

Wegner, R. \& Magruder, J., 2012, Missional moves: 15 tectonic shifts that transform churches, communities, and the world, Zondervan, Grand Rapids, MI.

World Council of Churches (WCC), 2013, 'Together towards life: Mission and evangelism in changing landscapes', World Council of Churches 10th General Assembly, Busan, Republic of Korea, 30th October - 08th November 2013. 